\title{
Different mechanisms are implicated in ERBB2 gene overexpression in breast and in other cancers
}

\author{
D Vernimmen', M Gueders', S Pisvin², P Delvenne ${ }^{2}$ and R Winkler*,I \\ 'Molecular Oncology Laboratory, Experimental Cancer Research Center, Liège University, B-4000 Liège, Belgium; ${ }^{2}$ Pathology Department, Experimental \\ Cancer Research Center, Liège University, B-4000 Liège, Belgium
}

The ERBB2 gene is overexpressed in 30\% of breast cancers and this has been correlated with poor prognosis. ERBB2 is upregulated in other cancers such as prostate, pancreas, colon and ovary. In breast cancer cells, the mechanisms leading to ERBB2 gene overexpression are increased transcription and gene amplification. In these cancers, AP-2 transcription factors are involved in ERBB2 overexpression, and AP-2 levels are correlated with pl85 $85^{\mathrm{c}-e r b B-2}$ levels. In this work, we wanted to know if the same molecular mechanisms are responsible for the ERBB2 upregulation in non-breast cancers. We compared ERBB2 gene copy number, $\mathrm{p} / 85^{\mathrm{c}-\mathrm{erbB}-2}$ and mRNA levels with AP-2 levels in several ovary, prostate, colon and pancreas cancer cells. A moderate expression of erbB-2 mRNA and protein were observed in some cells without gene amplification. In contrast to breast cancer cells, AP-2 factors were absent or low in some non-breast cells which did express ERBB2. It is thus likely that AP-2 is not a major player in the increased levels of erbB-2 transcripts in non-breast cancer cells. The transcriptional activity of the ERBB2 promoter in colon and ovary cancer cells was estimated using reporter vectors. The results showed that the promoter regions involved in ERBB2 gene overexpression in breast cancer cells are different from those that lead to the gene upregulation in colon and ovary cancers. In conclusion, our results indicate that different transcriptional and post-transcriptional mechanisms are responsible for the increased levels of erbB-2 transcript and protein in breast and non-breast cancer cells.

British Journal of Cancer (2003) 89, 899-906. doi: I0.1038/sj.bjc.660I200 www.bjcancer.com

(c) 2003 Cancer Research UK

Keywords: immunocytochemistry; ERBB2 promoter; AP-2 transcription factor; human

The ERBB2 gene is located on chromosome $17 \mathrm{q} 21$ and encodes a $185 \mathrm{kDa}$ transmembrane receptor $\left(\mathrm{p} 185^{\mathrm{c}-e r b \mathrm{~B}-2}\right)$ belonging to the EGFR family (Yarden and Sliwkowski, 2001). ERBB2 is overexpressed in about $30 \%$ of breast and ovary cancers and this has been correlated with poor prognosis for the patient (Ross and Fletcher, 1999). Recently, the use of a p185 cerbB-2 targeted antibody, trastuzumab (Herceptin), has been used successfully to inhibit the growth of breast cancer cells.

Most of the studies aimed at understanding the molecular basis of ERBB2 overexpression have been performed in breast cancers. In these cancers, the molecular mechanisms involved are transcriptional upregulation and gene amplification (Hollywood and Hurst, 1993; Pasleau et al, 1993). AP-2 and Ets family transcription factors have been shown to contribute to ERBB2 overexpression in breast cancer cells. The AP-2 transcription factors upregulate the ERBB2 expression by binding to two sites located $-213 \mathrm{bp}$ (Bosher et al, 1996) and $-500 \mathrm{bp}$ upstream the Cap site (Vernimmen et al, 2003). The Ets transcription factor stimulates ERBB2 expression by preventing the formation of a triplex structure on the core promoter (Scott et al, 2000).

*Correspondence: Dr R Winkler; E-mail: rwinkler@ulg.ac.be Received 19 February 2003; revised 19 June 2003; accepted 24 June 2003
The ERBB2 gene is also overexpressed in other cancers such as prostate, colon and pancreas cancers, and this alteration has also been considered as a negative prognosis marker by some authors (Klapper et al, 2000).

In this report, we address, for the first time, the molecular mechanisms leading to ERBB2 gene overexpression in non-breast cancer cells. We wanted to know if the mechanisms, which have been shown to operate in breast cancers, are also at work in nonbreast cancers. For this purpose, we used cell lines derived from ovary, prostate, colon, liver and pancreas cancers. First, we compared the ERBB2 gene copy number, mRNA and protein levels. The p $185^{\mathrm{c}-e r b \mathrm{~B}-2}$ levels were estimated by immunocytochemistry (ICC) and Western blotting. The ERBB2 gene copy numbers and mRNA levels were measured by real-time PCR. In parallel, we assessed the AP-2 levels and DNA binding activities in all these cell lines. The results showed a moderate ERBB2 overexpression in a significant proportion of non-breast cancer cells. Contrary to the results obtained in breast cancer cell lines, there was no correlation between the levels of the erbB-2 mRNA and the AP-2 transcription factor. We then analysed the $E R B B 2$ promoter activity in the different cell lines by transfecting reporter vectors containing progressive deletions of a $6 \mathrm{~kb}$ promoter (Grooteclaes et al, 1994). The transcriptional activity increased with increasing sizes of the ERBB2 promoter. Nevertheless, the regulatory fragments we identified in breast cancer cells (Grooteclaes et al, 1994) function differently in non-breast cancer cells. In conclusion, the accumulation of erbB-2 mRNA and protein in breast and non-breast cancer 
cells are the consequences of different transcriptional and/or posttranscriptional events.

\section{MATERIAL AND METHODS}

\section{Cell lines}

The mammary (BT-474, ZR-75.1 and MDA-MB-231), hepatic (HepG2), prostatic (LNCaP, DU 145 and PC-3), colon (WiDr, HTm29, HCT 116, COLO 205 and COLO 320), ovary (OVCAR-3 and SK-OV-3) and pancreatic (PANC-1, Miapaca-2, HS766 T, CFPAC-1, SU.86.86, BxPC-3 and Capan-2) human epithelial cells were purchased from American Type Culture Collection (Manassas, VA, USA) and cultured in the recommended media supplemented with $10 \%$ fetal bovine serum, $2 \mathrm{~mm}$ glutamine and $100 \mu \mathrm{g} \mathrm{ml}^{-1}$ penicillin/streptomycin. (Biowhittaker, Walkersville, MD, USA).

\section{Immunocytochemistry}

Cells $\left(50 \times 10^{6}\right)$ were harvested by trypsinisation and centrifugation. After centrifugation, the cell pellets were fixed in $2 \%$ paraformaldehyde (UCB, Louvain, Belgium), then embedded in paraffin. Sections (5 $\mu \mathrm{m}$ thick) were deparaffinized and rehydrated using xylene and graded alcohols. The sections were heated at $100^{\circ} \mathrm{C}$ for $40 \mathrm{~min}$ in a citrate buffer, then incubated for $20 \mathrm{~min}$ at room temperature. Endogenous peroxidase activity was blocked with $5 \% \mathrm{H}_{2} \mathrm{O}_{2}$ for 5 min. After two washes, for $5 \mathrm{~min}$ each, with $1 \%$ tween-phosphate-buffered saline (PBS) solution, the sections were incubated with an antibody diluent solution (Dako Diagnostics, Glostrup, Denmark) containing a c-erbB-2 monoclonal antibody $(1: 300)$ raised against the internal domain of the $\mathrm{p} 185^{\mathrm{c}-e r b \mathrm{~B}-2}$ protein (NCL-CB11, Novocastra, Newcastle, UK). Anti-mouse HRP-labelled polymer (Dako) was applied for $30 \mathrm{~min}$ at room temperature and the slides were washed for $2 \times 5 \mathrm{~min}$ with $1 \%$ tween-PBS solution. The sections were then incubated for $40 \mathrm{~min}$ with $\mathrm{DAB}^{+}$substrate (Dako), washed three to four times in water and counterstained with haematoxylin. Cytoplasmic and membrane immunostaining was evaluated using a 0 to $3+$ scale $(0$, negative or equivocal positivity; $1+$, weak positivity; $2+$ moderate positivity; $3+$ strong positivity).

\section{Real-time PCR and real-time RT-PCR}

Genomic DNA was extracted by the phenol-chloroform procedure (Maniatis et al, 1982). Total cellular RNA was extracted with the Tripure Isolation Reagent (Roche Diagnostic, Basel, Switzerland). DNA and RNA quantification were performed with the LightCycler-HER2/neu DNA and RNA Quantification Kits (Roche).

\section{Electromobility shift assays (EMSA)}

Nuclear extracts, HTF/AP-2 cis sequence and EMSA were described elsewhere (Schreiber et al, 1989; Vernimmen et al, 2003). Briefly, $2-4 \mu \mathrm{g}$ of crude nuclear proteins were incubated with 300000 c.p.m. of $\left[\alpha-{ }^{32} \mathrm{P}\right] \mathrm{dCTP}$ end-labelled oligonucleotide. The retarded complexes were analysed on a nondenaturing $5 \%$ polyacrylamide gel and analysed using a PhosphorImager (Molecular Dynamics Amersham Biosciences, Roosendal, The Netherlands).

\section{Western blotting}

For $\mathrm{p} 185^{\mathrm{c}-e r b \mathrm{~B}-2}$ detection, cells were scraped off the culture dishes, harvested in PBS, pelleted by centrifugation, resuspended in a $1 \%$ SDS solution and boiled for $10 \mathrm{~min}$. Whole cell extracts $(20 \mu \mathrm{g})$ were loaded per well, separated on a $12 \%$ SDS-polyacrylamide gel and transferred to a PVDF membrane
(Millipore, Brussels, Belgium). A c-erbB-2 antibody (06-562 Euromedex, Mundolsheim, France) was used at a $1: 2000$ dilution. For AP-2 detection, $10-25 \mu \mathrm{g}$ of nuclear extracts were loaded per well. An AP- $2 \alpha$ antibody (sc-184 Santa Cruz Biotechnology, Santa Cruz, CA, USA) was used at a 1:700 dilution. Secondary antibodies (Dako Diagnostics, Glostrup, Denmark) were detected with the ECL system (Amersham BioSciences). The $\beta$-actin monoclonal antibody was from Sigma (monoclonal (amoeba) mouse ascites fluid clone KJ43A Sigma-Aldrich Bernem, Belgium).

\section{Plasmids and transient transfection assays}

The transfection efficiencies of all the cell lines were tested by transfection of the pEGFP-IRESpuro control vector (Clontech, Palo Alto, CA, USA). Cells were transfected using the FuGENE 6 reagent (Roche). Cells $\left(4 \times 10^{5}\right)$ were plated on $35 \mathrm{~mm}$ tissue culture dishes with a FuGENE/DNA ratio of $3: 1$. The cells were incubated for $48 \mathrm{~h}$ in complete medium. Cells transfected with the green fluorescent protein (GFP) expression plasmid were visualised by fluorescent microscopy. The luciferase (LUC) reporter vectors containing different ERBB2 promoter fragments have been previously described (Grooteclaes et al, 1994). The LUC enzymatic activities were measured using the Luciferase Reporter Gene Assay kit (Roche).

\section{RESULTS}

ErbB-2 gene copy number, mRNA and protein levels in cancer cell lines

We measured the $\mathrm{p} 185^{\mathrm{c}-e r b \mathrm{~B}-2}$ protein levels by ICC and Western blotting. For ICC, we used the well characterised breast cancer cell lines BT-474 and ZR-75-1 as standards to determine the erbB2 expression in the non-breast cells (Figure 1A, C). After ICC, p185 ${ }^{\mathrm{c}-e r b \mathrm{~B}-2}$ appeared as a brown membrane staining in positive breast cancer cells. Likewise, $\mathrm{p} 185^{\mathrm{c}-e r b \mathrm{~B}-2}$ exhibited an intense membranous staining in SK-OV-3 ovary carcinoma cells (Figure 1B). P185 ${ }^{\mathrm{c}-e r b \mathrm{~B}-2}$ was detected in one out of two ovary, four out of five colorectal, three out of three prostatic and only two out of seven pancreatic cancer cells, but the staining was heterogeneous and mainly cytoplasmic (Figure 1D and Table 1). $\mathrm{P} 185^{\mathrm{c}-e r b \mathrm{~B}-2}$ was also detected in the cytoplasm of HepG2 hepatocarcinoma cells (Figure 1E). Figure 1F presents a pancreatic cell line negative for $\mathrm{p} 185^{\mathrm{c}-e r b \mathrm{~B}-2}$.

The $185^{\mathrm{c}-e r b \mathrm{~B}-2}$ levels were also estimated by Western blotting of whole-cell extracts (Table 1 and Figure 4). As cell density has been reported to modulate $\mathrm{p} 185^{\mathrm{c}-e r b \mathrm{~B}-2}$ levels in breast cancer cells (Kornilova et al, 1992), we compared the oncoprotein levels in low ( $50 \%$ confluence)- and high ( $100 \%$ confluence)-density cultures. The full-length, $185 \mathrm{kDa}$ protein, was detected in most analysed cells. A slight difference was observed between lowand high-density cultures of breast, ovary and pancreatic cell lines (Figure 4). The highest $\mathrm{p} 185^{\mathrm{c}-e r b \mathrm{~B}-2}$ levels were observed in BT-474 breast and SK-OV-3 ovary cancer cells (Table 1). In order to compare the protein content between the different cancer types, we attributed the value of one to the $185^{\mathrm{c}-e r b \mathrm{~B}-2}$ measured in MDA-MB-231 mammary cancer cells (Table 1). BT-474 and SK-OV-3 cells contained the highest protein levels associated with gene amplification and mRNA overexpression. Among the cells without gene amplification, HepG2 hepatocarcinoma and $\mathrm{LNCaP}$ prostate cancer cells were most enriched in $185^{\mathrm{c}-e r b \mathrm{~B}-2}$. All the colon cancer cell lines contained almost similar protein levels not significantly different from that of MDA-MB-231 cells. The pancreatic cell lines SU.86.86, BxPC-3, HS766 T and PANC-1 contained very low levels of $\mathrm{p} 185^{\mathrm{c}-e r b \mathrm{~B}-2}$, detectable only after long exposure time. Only 

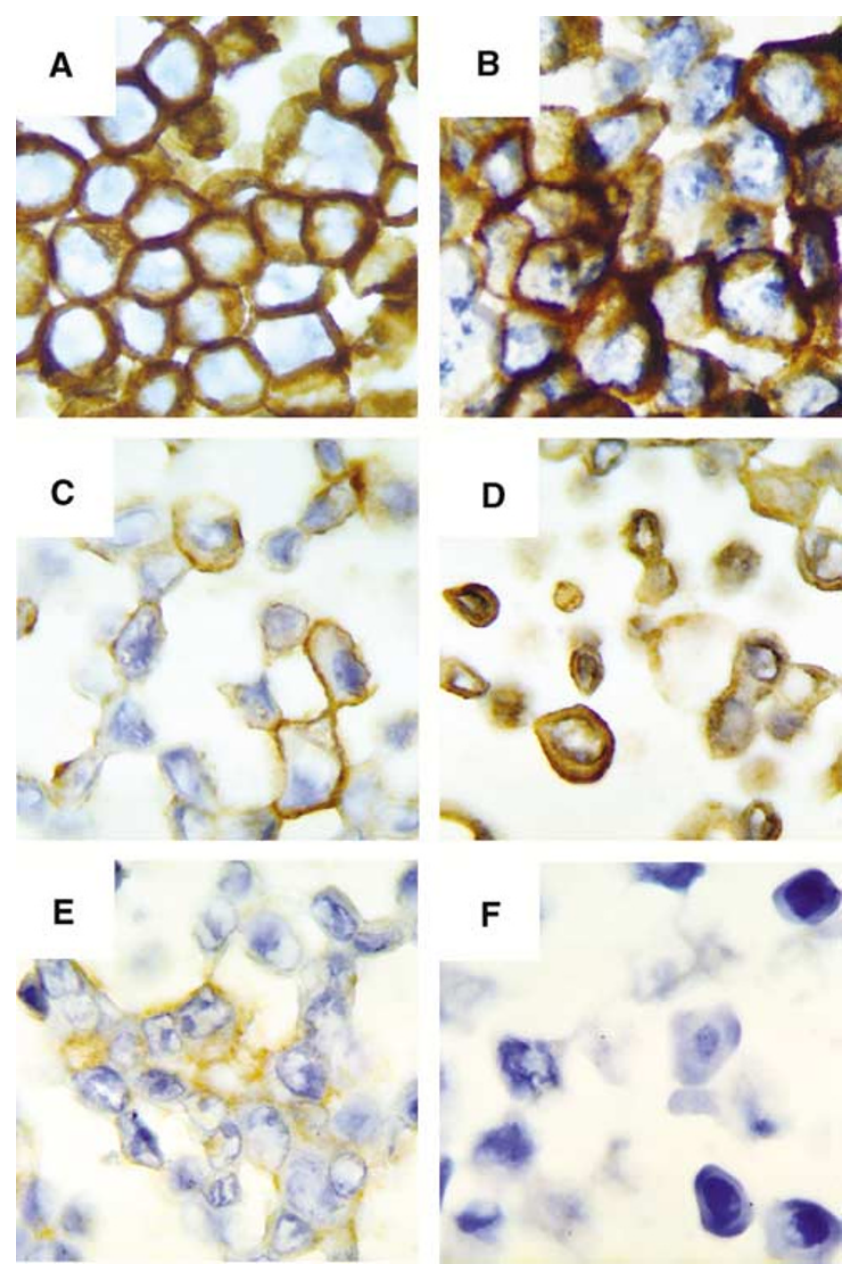

Figure I Representative examples of $\mathrm{p} / 85^{\mathrm{c}-\mathrm{erb} B-2}$ immunostaining in cancer cell lines. (A) BT-474 (mammary cell line with ERBB2 amplification and $3+$ membrane overexpression). (B) SK-OV-3 (ovary cell line with ERBB2 amplification and $3+$ membrane overexpression). (C) ZR-75.I (mammary cell line without ERBB2 amplification and $2+$ membrane overexpression). (D) HTm29 (colon cell line without ERBB2 amplification and $2+$ cytoplasmic/I + membrane overexpression). (E) HepG2 (liver cell line without ERBB2 amplification and $2+$ cytoplasmic overexpression). (F) SU.86.86 (pancreatic cell line without ERBB2 amplification and no cytoplasmic/membrane expression)(magnification X400).

CF-PAC-1, Miapaca-2 and Capan-2 cells attained or slightly exceeded the MDA-MB-231 p185 ${ }^{\mathrm{c}-e r b \mathrm{~B}-2}$ levels. Notice the wide variation in $\mathrm{p} 185^{\mathrm{c}-e r b \mathrm{~B}-2}$ between the pancreatic cancer cells. In general, Western blotting and ICC results were in reasonably good agreement (Table 1).

The erbB-2 mRNA levels were measured by real-time RT - PCR. The results are summarised in Table 1 and compared to the Western blotting data. In most cells, real-time RT-PCR and Western blotting data were in good agreement, except for the COLO 320 cancer cells. Indeed, in these cells, the increase in transcript levels was not accompanied by an increase in protein levels (Table 1). Like the protein levels, erbB-2 mRNA levels were quite high in HepG2 cells.

The ERBB2 gene copy numbers were estimated by real-time PCR in all cancer cells (Table 1). The gene was not amplified in any of the prostate, colon and pancreatic cancer cells. SK-OV-3 presents a four-fold amplification of the ERBB2 gene.

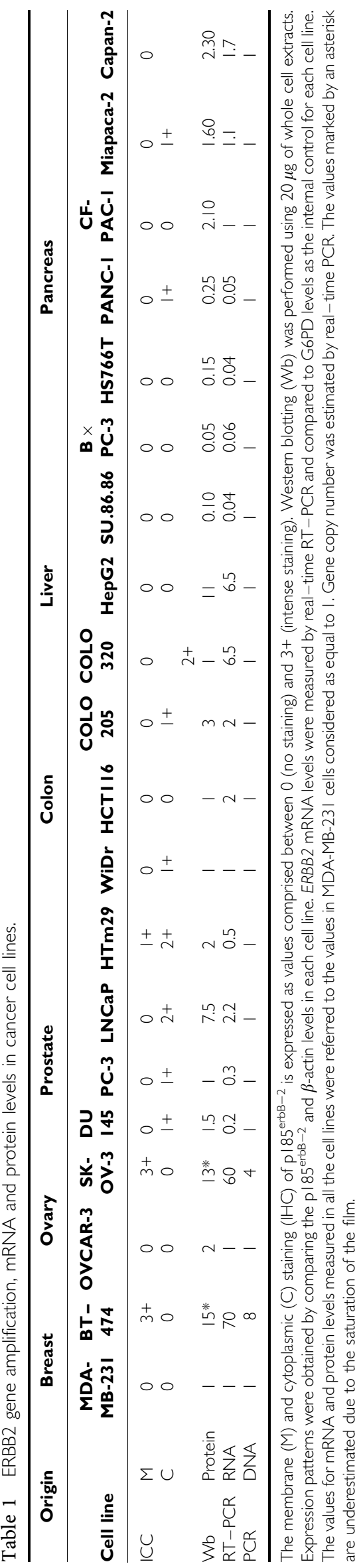



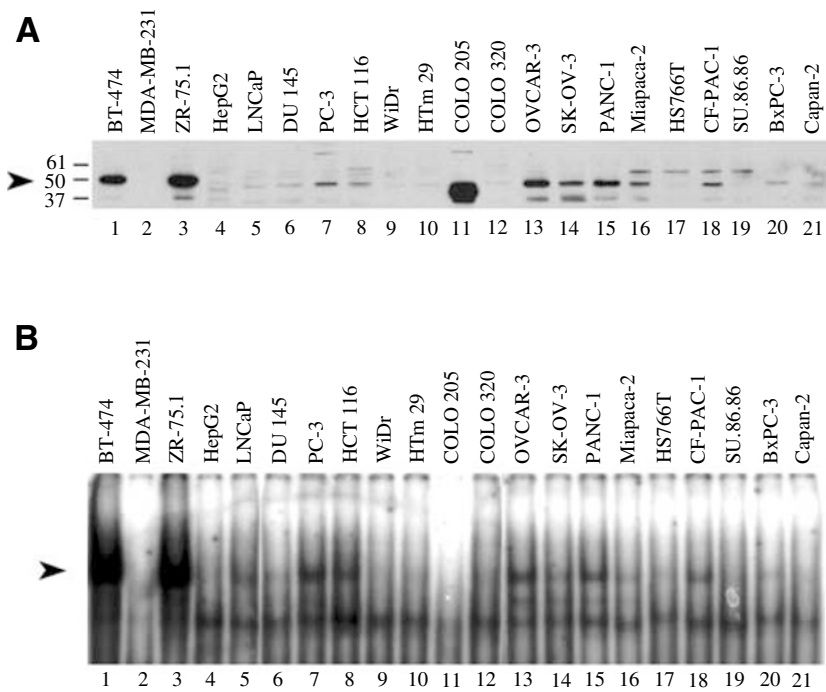

Figure 2 Distribution of AP-2 transcription factor in non-breast cancer cell lines. (A) Western blot with I0 $\mu \mathrm{g}$ (control, lanes I and 3) or $20 \mu \mathrm{g}$ (lanes 2 and 4-2I) of crude nuclear extracts from breast and non-breast cells. The arrowhead marks the $50 \mathrm{kDa}$ molecular weight of AP-2 proteins. (B) EMSA assays with $2 \mu \mathrm{g}$ (lanes I and 3) or $4 \mu \mathrm{g}$ (lanes 2 and 4-2I) of crude nuclear extracts. The arrowhead marks specific AP-2/DNA complex.

\section{AP-2 transcription factors are not involved in ERBB2 overexpression in non-breast cancer cells}

AP-2 levels are high in most breast cancer cells overexpressing ERBB2 (Bosher et al, 1996). To find out if these transcription factors are also involved in the stimulation of $E R B B 2$ expression in non-breast cancer cells, we compared AP-2 and erbB-2 levels in the cell lines used in this study. AP- $2 \alpha$ levels were estimated by Western blotting (Figure 2A) and AP-2 DNA binding activity was analysed by gel retardation experiments (EMSA) (Figure 2B). BT-474 and ZR-75.1 breast cancer cells were used as AP-2-positive controls and HepG2 hepatocarcinoma cells and MDA-MB-231 breast cancer cells as AP-2-negative controls (Bosher et al, 1996). AP-2 levels were very low in colon cancer cells (Figure 2A, lanes $8-12$ ). Interestingly, in COLO 205 cells, the AP-2 antibody revealed three intense bands of lower molecular weight (Figure 2A, lane 11). No DNA binding activity was detected in these cells (Figure 2B, lane 11), suggesting that this might be a false positive signal. Low levels of the $50 \mathrm{kDa}$ AP-2 factor were detected in prostate cancer cells (Figure 2A, lanes 5-7). In the two ovary cancer cell lines, AP- $2 \alpha$ was easily detected (Figure 2A, lanes 13,14). However, the signal was much less intense than in breast cancer cells overexpressing AP-2 (see for instance Figure 2A, lanes 1 and 3). Finally, in the pancreatic cells, the AP- $2 \alpha$ levels were low to moderate. In these cells, a higher molecular weight band was detected together with the $50 \mathrm{kDa}$ protein (Figure 2A, lanes 15-21). The Western blotting and the EMSA results showed comparable patterns in all the cell lines, indicating that when AP-2 was present, it binds efficiently to DNA.

In conclusion, there was no correlation between AP-2 and erbB2 mRNA or protein levels in the non-breast cancer cell lines. The most striking discrepancy was observed with HepG2 cells, widely used as AP-2 negative controls, but these cells do express the erbB2 mRNA and protein. Our results thus suggest that the AP-2 is not involved in ERBB2 overexpression in the non-breast cancer cell lines we tested.

\section{ERBB2 promoter activity in non-breast cancer cells}

In order to better understand the mechanisms leading to ERBB2 overexpression in the non-breast cancer cells, we transfected reporter vectors containing progressive deletions of a $6 \mathrm{~kb}$ promoter fragment (Figure $3 \mathrm{~A}$ ). We have shown previously that these promoter fragments are active in breast cancer cells (Grooteclaes et al, 1994). The transfection efficiencies of all the cell lines were estimated by transfection of an EGFP-expression vector (data not shown). Only the cells having a transfection efficiency of at least 5\%, namely colon and ovary cancer cells, were used for further studies. The luciferase activity was compared in cell lines synthesising low $v s$ high levels of the erbB-2 transcript (HCT 116 vs COLO 320; OVCAR-3 vs SK-OV-3). In both colorectal cell lines (HCT116 and COLO 320), the $6 \mathrm{~kb}$ promoter fragment induced a 2.5 -fold increase of the LUC activity compared to the vector containing $200 \mathrm{bp}$ of the promoter (Figure 3B, lane 4 and $3 \mathrm{C}$, lane 4). The low-ERBB2-expressing ovary cancer cells, OVCAR-3, showed an increase of the LUC activity with the promoter size (Figure 3D). This increase was similar to that observed in the colorectal cells (compare Figure 3B-D). Only the p756-LUC construct increased the LUC activity in ERBB2overexpressing SK-OV-3 cells (Figure 3E, lane 2). The longer promoter fragments downregulated the transcriptional activity to the basal value (Figure 3E, lanes 3 and 4). It is interesting to note that in this cell line the ERBB2 gene is amplified four-fold and overexpressed more than 60 times (King et al, 1992 and personal results, Table 1).

\section{DISCUSSION}

Around $30 \%$ of breast cancers overexpress the ERBB2 gene and this is correlated with a poor prognosis. Besides gene amplification, several investigators have described the involvement of ETS family (Scott et al, 2000) and AP-2 family (Bates and Hurst, 1997) transcription factors in the gene overexpression. ERBB2 overexpression has also been reported in cancers of colon (Nakae et al, 1993; Kapitanovic et al, 1994; Maurer et al, 1998), prostate (Ross et al, 1993; Morote et al, 1999), ovary (Fajac et al, 1995) and pancreatic (Yamanaka et al, 1993) origin. However, the mechanisms leading to increased expression of the gene have not been investigated in these tumours. Gene amplification is rare in these tumours and cannot account for the observed increase in the mRNA or protein levels. To our knowledge, this is the first attempt to understand the molecular mechanisms leading to ERBB2 overexpression in nonbreast cancers.

First, we assessed $\mathrm{p} 185^{\mathrm{c}-e r b \mathrm{~B}-2}$ levels by ICC and by Western blotting. One of the main observations of this study is that breast and ovary cancer cell lines were characterised by a membrane homogeneous staining, whereas in the non-breast cancer cells, the staining was cytoplasmic and heterogeneous (Figure 1, Table 1). Several truncated intracellular p $185^{\mathrm{c}-e r b \mathrm{~B}-2}$ fragments have been described (Scott et al, 1993; Esparis-Ongando et al, 1999; Christianson et al, 1998; Molina et al, 2002). These fragments, which signal actively, might be responsible for the cytoplasmic staining observed in most non-breast cancer cells. However, only the full-length protein was detected by Western blotting in these cells, which does not support the hypothesis that ICC detects a truncated cytoplasmic protein. The cytoplasmic staining of p $185^{\mathrm{c}-e r b \mathrm{~B}-2}$ has already been reported in prostate cancers (Rosset et al, 1993). De Potter et al (1989) have described the presence of a protein on the mitochondrial membrane, appearing as granular staining in the cytoplasm. The significance of the cytoplasmic staining in breast cancer cells is controversial, since some authors did not observe a correlation between the cytoplasmic protein and the mRNA levels (DiGiovanna, 1999; Ross and Fletcher, 1999). However, in the non-breast cancer cells we 

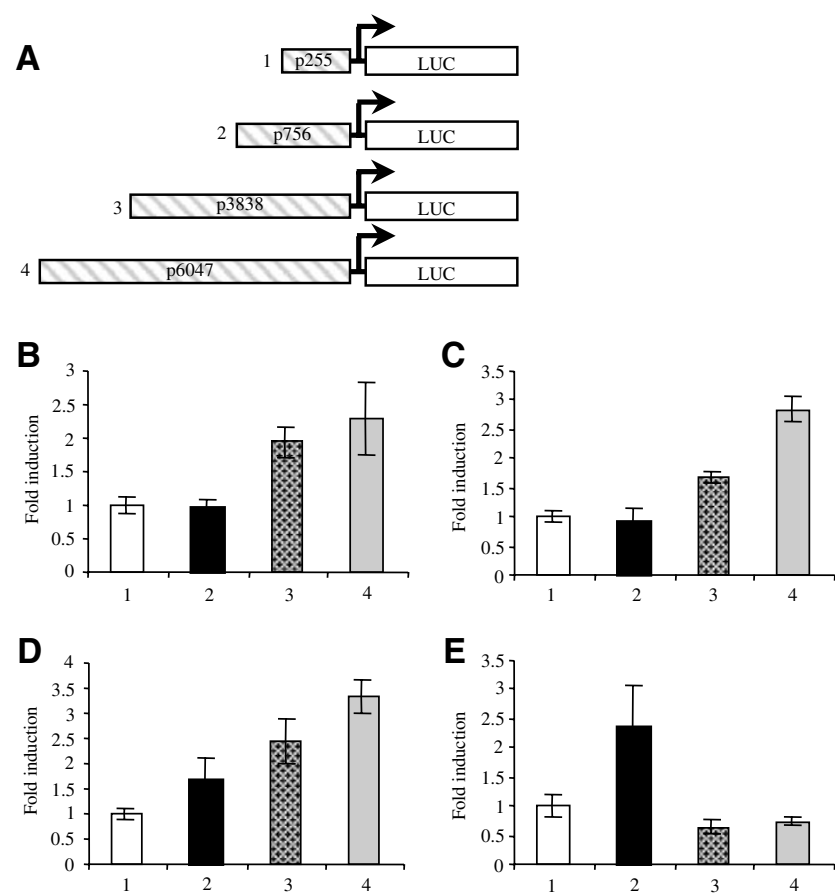

Figure 3 Luc assays using different ERBB2 promoter constructs. (A) Illustration of the different reporter vectors used. The promoter fragment sizes are indicated in the hatched boxes. The luciferase activity was measured in colon HCT II 6 (B), COLO 320 (C) and ovary OVCAR-3 (D) and SK-OV-3 (E) cancer cells. The results are expressed as fold induction compared to the level obtained with the p255-LUC vector. The data are shown as the mean \pm s.d. of triplicate experiments.

have analysed, there was a good correlation between these parameters. The mechanism by which $\mathrm{p} 185^{\mathrm{c}-e r b \mathrm{~B}-2}$ is mainly cytoplasmic is unknown. The protein might not be properly targeted to the membrane or, alternatively, might be internalised (DiGiovanna, 1999).

We have characterised the ERBB2 gene copy number, mRNA and protein levels in the tumour cell lines investigated in this study. Gene amplification was detected only in BT-474, MDA-MB453 and SK-OV-3 cell lines, which is in good agreement with already published data. LNCaP prostate carcinoma cells, three pancreatic cells (Miapaca-2, Capan-2 and CF-PAC-1) and three colon cancer cells (HCT116, COLO 205 and COLO 320) showed a significant increase in erbB-2 mRNA levels without gene amplification. Compared with breast cancer cells, the increase in the transcript levels in these cells was low to moderate. HepG2 hepatocarcinoma cells expressed quite high levels of erbB-2 mRNA and protein. Indeed, the mRNA level was about the same as in COLO 320 cells but the protein level was much higher than in colon cancer cells.

The increased levels of $\mathrm{p} 185^{\mathrm{c}-e r b \mathrm{~B}-2}$ have been shown to affect the biology of the tumour. For instance, increased p $185^{\mathrm{c}-e r b \mathrm{~B}-2}$ levels in prostate cancers were associated with the passage from the androgen-dependent to the hormoneindependent status (Signoretti et al, 2000). ErbB2 might stimulate the proliferation of colon cancer cells by upregulating COX2 (Mann et al, 2001).

In the ovary, prostate and pancreas cells, a good correlation was observed between the relative protein and mRNA levels (Figure 4). On the contrary, in colon cancers, we observed an increase in mRNA levels while the protein levels were unchanged. We suggest two explanations for this discrepancy. First, the messenger RNA translation could be less efficient in
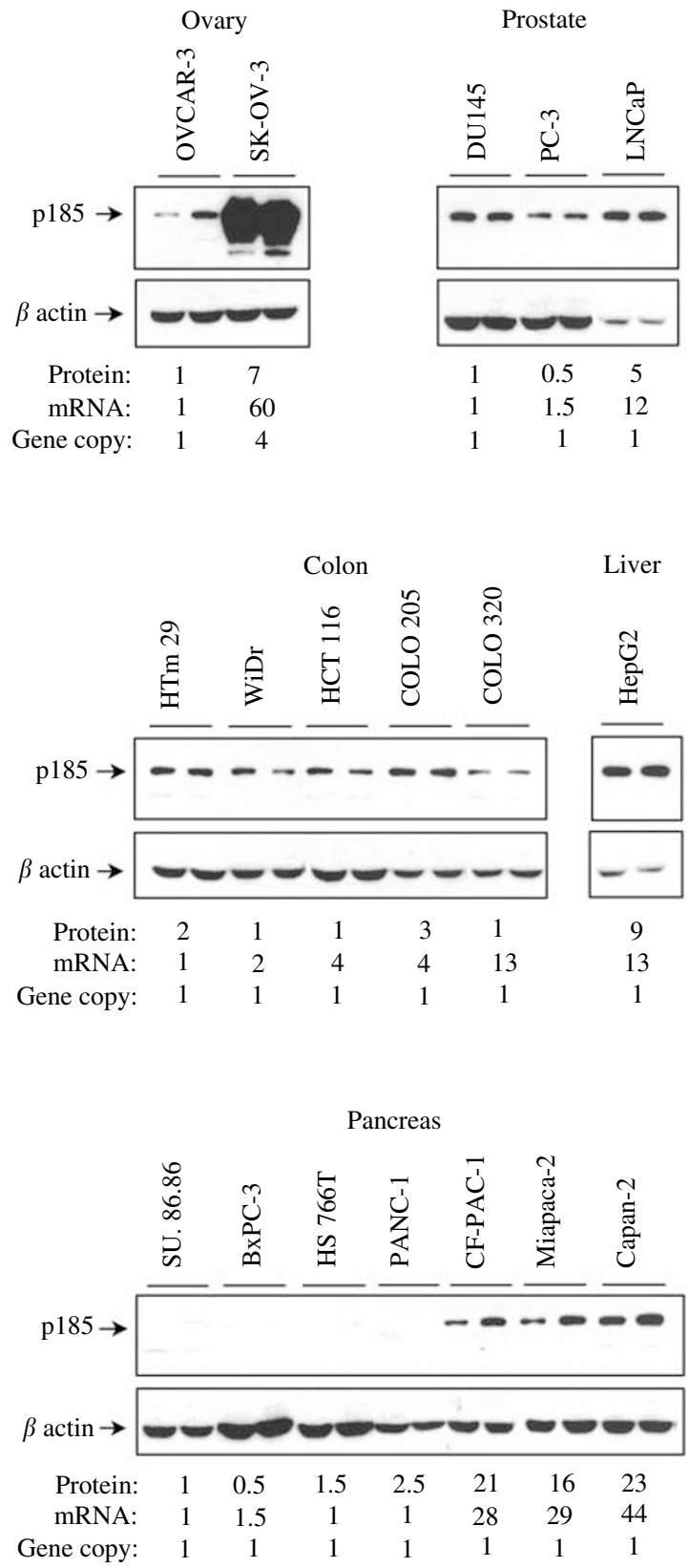

Figure 4 Expression of pl85-erbB-2 and erbB-2 messenger RNA in cancer cell lines. The first and the second lanes for each cell line correspond to pre-confluent and confluent cultures respectively. In order to compare the protein content in each cancer type, the value of one was given to the cell line expressing the lowest level of p $185^{c-e r b B-2}$ protein. The indicated values for protein and mRNA correspond to those measured for confluent cells.

colon cancer cells. Indeed, Child et al (1999) have shown that the erbB-2 transcript is translated with different efficiencies in different cell lines. Second, the protein half-life might be shorter in these cells. Future studies are needed to address these questions.

As a first approach to the understanding of ERBB2 gene expression regulation in non-breast cancer cell lines, we compared ERBB2 expression levels with AP- $2 \alpha$ protein levels and with AP-2 DNA binding activity in these cells. As EMSA detects the binding of AP- $\alpha, \beta$ and $\gamma$ transcription factors, this technique gives a more 
accurate picture of AP-2 transcriptional activity than the Western blotting. We analysed the possible involvement of AP-2 in the increased $E R B B 2$ expression, because of the well-characterised role of this transcription factor in breast cancer cells. Indeed, the 500 bp proximal ERBB2 promoter contains two AP-2 binding sites, which contribute to the gene overexpression. The first site is located $215 \mathrm{bp}$ upstream from the transcription initiation site (Bosher et al, 1995), whereas the second lies $501 \mathrm{bp}$ upstream from the transcription start site (Grooteclaes et al, 1999; Vernimmen et al, 2003).

Nuclear AP- $2 \alpha$ levels and AP-2 DNA binding activities were considerably lower in prostate, colon, ovary and pancreatic cell lines than in breast cancer cells. Since AP-2 could be cytoplasmic rather than nuclear (see below), we also analysed whole-cell extracts by Western blotting. We did not observe any difference between nuclear and total AP-2 levels, indicating that the low levels of the nuclear factor is not the consequence of its cytoplasmic retention (data not shown). Besides the full-length $50 \mathrm{kDa}$ protein, we detected lower and higher molecular weight proteins as well. The lower molecular weight bands might result from the proteolysis of the transcription factor. Higher molecular weight immunoreactive forms were observed mainly in the pancreatic cells (Figure 2A) and might represent the recently described, $60 \mathrm{kDa}$ sumolated form of the protein. The transcriptional activity of these sumolated factors is reduced (Eloranta and Hurst, 2002).

AP- $2 \alpha$ levels were not correlated with ERBB2 expression in nonbreast cancer cell lines. This indicates that AP-2 is not involved in $E R B B 2$ gene overexpression. In other cancers, the role of AP-2 has been shown to vary according to the tumour type. Some authors described the loss of AP- $2 \alpha$ expression early in the development of prostate adenocarcinoma (Ruiz et al, 2001). Moreover, AP-2B, a dominant-negative variant of AP- $2 \alpha$, was detected by RT - PCR in LNCaP cells (Buettner et al, 1993). Others did detect AP- $2 \alpha$ by immunohistochemistry in some prostate cancer specimens (Lipponen et al, 2000). In primary colorectal (Ropponen et al, 2001) and ovarian cancers (Anttila et al, 2000), AP-2 $\alpha$ was detected in the nucleus or the cytoplasm of tumour cells. However, the presence of the transcription factor in the cytoplasm precludes its function in transcription. Interestingly, high AP- $2 \alpha$ mRNA levels were detected in some tumours which were negative for the protein (Karjalainen et al, 2000).

To analyse the molecular mechanisms leading to ERBB2 overexpression in non-breast cancer cell lines, we transfected four LUCIFERASE reporter vectors containing $200 \mathrm{bp}-6 \mathrm{~kb}$ fragments of the ERBB2 promoter in colon and ovary cell lines. The relative transcriptional activity of each reporter was compared to the luciferase activity induced by the p255-LUC vector, considered as equal to one (Grooteclaes et al, 1994). In the colorectal cancer cell lines, the $700 \mathrm{bp}$ fragment induced the same luciferase activity as the $200 \mathrm{bp}$ promoter. The absence of AP-2 in these cells could explain the result. Indeed, we have shown that AP-2 is responsible for the transcriptional activating properties of this fragment in breast cancer cells (Grooteclaes et al, 1999; Vernimmen et al, 2003). The $6 \mathrm{~kb}$ promoter fragment induced a comparable increase in transcriptional activity in both colorectal cell lines. The three-fold difference in erbB-2 mRNA levels between HCT116 and COLO 320 cells is probably too small to be reflected by a significant difference in the promoter activity
(Table 1). In SK-OV-3 ovary cancer cell line, overexpressing about 60 times the erbB-2 transcript, only the p756-LUC vector induced a significant increase in the transcription level (Figure $3 \mathrm{E}$, compare lanes 1 and 2). The longer promoter fragments repressed the transcription. On the contrary, in OVCAR-3 cells, which do not overexpress $E R B B 2$, we observed a progressive increase in transcriptional activity with longer promoter fragments. This result could be explained by the presence of a $8 \mathrm{~kb}$ transcript with an extended half-life in SK-OV-3 cells (Doherty et al, 1999a). Abnormal amounts of the erbB-2 mRNA could accumulate not only because of transcriptional upregulation, but also because of its stabilisation. We (Pasleau et al, 1993) and others (Hollywood and Hurst, 1993; Miller et al, 1994) have shown that mRNA stabilisation is not responsible for ERBB2 overexpression in breast cancer cells. However, this is not necessarily true for other cancers. Another possibility is that other regulatory elements, located outside the promoter region tested in this study, could influence ERBB2 expression in colon and ovary cancer cells. For instance, sequences described in the first intron (Newman et al, 2000) or $12 \mathrm{~kb}$ upstream the conventional start site of the ERBB2 gene (Nezu et al, 1999) should be studied. We also have to keep in mind the multiple levels of erbB-2 mRNA and protein expression regulation. Indeed, multiple erbB-2 transcripts have been described which give rise to different proteins (Scott et al, 1993; Doherty et al, 1999a, b; Siegel et al, 1999). Moreover, p $185^{\mathrm{c}-e r b \mathrm{~B}-2}$ is proteolytically cleaved to generate a soluble extracellular fragment and a constitutively active intracellular fragment (Zabrecky et al, 1991; Pupa et al, 1993; Esparis-Ogando et al, 1999). No single detection method is able to pick up all these important variants.

In summary, this study is, to our knowledge, the first attempt to understand the mechanisms of ERBB2 overexpression in nonbreast cancer cells. In these cells, the gene copy number is normal and the overexpression is moderate. Our results suggest that different mechanisms lead to ERBB2 overexpression in breast and in non-breast cancers. In contrast to breast cancer cells, in colon cancers the protein and transcript levels are not correlated, suggesting a regulation at the levels of translation and/or posttranslation. One of the main finding is that AP-2 transcription factors are probably not involved in the increase in erbB-2 transcript levels in tumours of non-breast origins. Fragments of the ERBB2 promote act differently in breast and in ovary or colon cancer cells we have analysed. Additional studies are needed to understand the mechanisms responsible for the increased accumulation of the erbB-2 transcript and protein in non-breast cancer cells.

\section{ACKNOWLEDGEMENTS}

We thank Dr R Kiss for the pancreatic cell lines, Drs J Piette, M Grooteclaes and L Delacroix for critically reading the manuscript. This work was supported by a Grant from the Belgian 'Fonds National pour la Recherche Scientifique (F.N.R.S.)', 'Fédération belge contre le Cancer', 'Centre Anticancéreux près l'Université de Liège' and 'Fondation pour promouvoir la Recherche à l'Ulg'. Rosita Winkler and Philippe Delvenne are Chercheur Qualifié du F.N.R.S. Douglas Vernimmen is a recipient of a Télévie Grant from the F.N.R.S.

\section{REFERENCES}

Anttila MA, Kellokoski JK, Moisio KI, Mitchell PJ, Saarikoski S, Syrjanen K, Kosma VM (2000) Expression of transcription factor AP-2alpha predicts survival in epithelial ovarian cancer. Br J Cancer 82: 1974-1983
Bates NP, Hurst HC (1997) Transcriptional regulation of type I receptor tyrosine kinases in the mammary gland. J Mammary Gland Biol Neoplasia 2: 153-163 
Bosher JM, Totty NF, Hsuan JJ, Williams T, Hurst HC (1996) A family of AP-2 proteins regulates c-erbB-2 expression in mammary carcinoma. Oncogene 13: $1701-1707$

Bosher JM, Williams T, Hurst HC (1995) The developmentally regulated transcription factor AP-2 is involved in c-erbB-2 overexpression in human mammary carcinoma. Proc Natl Acad Sci USA 92: $744-747$

Buettner R, Kannan P, Imhof A, Bauer R, Yim SO, Glockshuber R, Van Dyke MW, Tainsky MA (1993) An alternatively spliced mRNA from the AP-2 gene encodes a negative regulator of transcriptional activation by AP-2. Mol Cell Biol 13: 4174-4185

Child SJ, Miller MK, Geballe AP (1999) Cell type-dependent and -independent control of HER-2/neu translation. Int J Biochem Cell Biol 31: $201-213$

Christianson TA, Doherty JK, Lin YJ, Ramsey EE, Holmes R, Keenan EJ, Clinton GM (1998) NH2-terminally truncated HER-2/neu protein: relationship with shedding of the extracellular domain and with prognostic factors in breast cancer. Cancer Res 58: 5123-5129

De Potter CR, Quatacker J, Maertens G, Van Daele S, Pauwels C, Verhofstede C, Eechaute W, Roels H (1989) The subcellular localization of the neu protein in human normal and neoplastic cells. Int J Cancer 44: 969-974

DiGiovanna MP (1999) Clinical significance of HER-2/neu overexpression: Part I. Principles Practice Oncol 13: 1-10

Doherty JK, Bond CT, Hua W, Adelman JP, Clinton GM (1999a) An alternative HER-2/neu transcript of $8 \mathrm{~kb}$ has an extended 3'UTR and displays increased stability in SKOV-3 ovarian carcinoma cells. Gynecol Oncol 74: 408-415

Doherty JK, Bond CT, Jardim A, Adelman JP, Clinton GM (1999b) The HER-2/neu receptor tyrosine kinase gene encodes a secreted autoinhibitor. Proc Natl Acad Sci USA 96: 10869-10874

Eloranta JJ, Hurst HC (2002) Transcription factor AP-2 interacts with the SUMO-conjugating enzyme UBC9 and is sumolated in vivo. J Biol Chem 277: $30798-30804$

Esparis-Ogando A, Diaz-Rodriguez E, Pandiella A (1999) Signallingcompetent truncated forms of ErbB2 in breast cancer cells: differential regulation by protein kinase $\mathrm{C}$ and phosphatidylinositol 3-kinase. Biochem J 344: $339-348$

Fajac A, Benard J, Lhomme C, Rey A, Duvillard P, Rochard F, Bernaudin JF, Riou G (1995) c-erbB2 gene amplification and protein expression in ovarian epithelial tumors: evaluation of their respective prognostic significance by multivariate analysis. Int J Cancer 64: 146-151

Grooteclaes M, Pasleau F, Dijkmans H, Berzi P, Albert A, Winkler-Gol R (1994) The 6-kilobase c-erbB2 promoter contains positive and negative regulatory elements functional in human mammary cell lines. Cancer Res 54: $4193-4199$

Grooteclaes M, Vernimmen D, Plaza S, Pasleau F, Hodzic D, Winkler-Gol R (1999) A new cis element is involved in the HER2 gene overexpression in human breast cancer cells. Cancer Res 59: 2527-2531

Hollywood DP, Hurst HC (1993) A novel transcription factor, OB2-1, is required for overexpression of the proto-oncogene c-erbB-2 in mammary tumour lines. EMBO J 12: 2369-2375

Kapitanovic S, Spaventi R, Poljak L, Kapitanovic M, Pavelic ZP, Gluckman JL, Spaventi S, Pavelic K (1994) High c-erbB-2 protein level in colorectal adenocarcinomas correlates with clinical parameters. Cancer Detect Prev 18: $97-101$

Karjalainen JM, Kellokoski JK, Mannermaa AJ, Kujala HE, Moisio KI, Mitchell PJ, Eskelinen MJ, Alhava EM, Kosma VM (2000) Failure in posttranscriptional processing is a possible inactivation mechanism of AP2alpha in cutaneous melanoma. Br J Cancer 82: 2015-2021

King BL, Carter D, Foellmer HG, Kacinski BM (1992) Neu proto-oncogene amplification and expression in ovarian adenocarcinoma cell lines. Am J Pathol 140: 23-31

Klapper LN, Kirschbaum MH, Sela M, Yarden Y (2000) Biochemical and clinical implications of the ErbB/HER signaling network of growth factor receptors. Adv Cancer Res 77: 25-79

Kornilova ES, Taverna D, Hoeck W, Hynes NE (1992) Surface expression of erbB-2 protein is post-transcriptionally regulated in mammary epithelial cells by epidermal growth factor and by the culture density. Oncogene 7: 511-519

Lipponen P, Aaltomaa S, Kellokoski J, Ala-Opas M, Kosma V (2000) Expression of activator protein 2 in prostate cancer is related to tumor differentiation and cell proliferation. Eur Urol 37: 573-578

Maniatis T, fritsch E, Sambrook J (1982) Molecular Cloning: a Laboratory Manual. New York: Cold Spring Harb Lab
Mann M, Sheng H, Shao J, Williams CS, Pisacane PI, Sliwkowski MX, DuBois RN (2001) Targeting cyclooxygenase 2 and HER-2/neu pathways inhibits colorectal carcinoma growth. Gastroenterology 120: $1713-1719$

Maurer CA, Friess H, Kretschmann B, Zimmermann A, Stauffer A, Baer HU, Korc M, Buchler MW (1998) Increased expression of erbB3 in colorectal cancer is associated with concomitant increase in the level of erbB2. Hum Pathol 29: 771-777

Miller S, Suen TC, Sexton T, Hung MC (1994) Mechanisms of deregulated HER2/neu expression in breast cancer cell lines. Int J Oncol 4: $599-608$

Molina MA, Saez R, Ramsey EE, Garcia-Barchino MJ, Rojo F, Evans AJ, Albanell J, Keenan EJ, Lluch A, Garcia-Conde J, Baselga J, Clinton GM (2002) $\mathrm{NH}(2)$-terminal truncated HER-2 protein but not full-length receptor is associated with nodal metastasis in human breast cancer. Clin Cancer Res 8: 347-353

Morote J, de Torres I, Caceres C, Vallejo C, Schwartz Jr S, Reventos J (1999) Prognostic value of immunohistochemical expression of the c-erbB-2 oncoprotein in metastatsic prostate cancer. Int J Cancer 84: $421-425$

Nakae S, Shimada E, Urakawa T (1993) Study of c-erbB-2 protein and epidermal growth factor receptor expression and DNA ploidy pattern in colorectal carcinoma. J Surg Oncol 54: 246-251

Newman SP, Bates NP, Vernimmen D, Parker MG, Hurst HC (2000) Cofactor competition between the ligand-bound oestrogen receptor and an intron 1 enhancer leads to oestrogen repression of ERBB2 expression in breast cancer. Oncogene 19: 490-497

Nezu M, Sasaki H, Kuwahara Y, Ochiya T, Yamada Y, Sakamoto H, Tashiro H, Yamazaki M, Ikeuchi T, Saito Y, Terada M (1999) Identification of a novel promoter and exons of the c-ERBB-2 gene. Biochem Biophys Res Commun 258: 499-505

Pasleau F, Grooteclaes M, Gol-Winkler R (1993) Expression of the c-erbB2 gene in the BT474 human mammary tumor cell line: measurement of c-erbB2 mRNA half-life. Oncogene 8: 849-854

Pupa SM, Menard S, Morelli D, Pozzi B, De Palo G, Colnaghi MI (1993) The extracellular domain of the c-erbB-2 oncoprotein is released from tumor cells by proteolytic cleavage. Oncogene 8: 2917-2923

Ropponen KM, Kellokoski JK, Pirinen RT, Moisio KI, Eskelinen MJ, Alhava EM, Kosma VM (2001) Expression of transcription factor AP-2 in colorectal adenomas and adenocarcinomas; comparison of immunohistochemistry and in situ hybridisation. J Clin Pathol 54: $533-538$

Ross JS, Fletcher JA (1999) HER-2/neu (c-erb-B2) gene and protein in breast cancer. Am J Clin Pathol 112: S53-S67

Ross JS, Nazeer T, Church K, Amato C, Figge H, Rifkin MD, Fisher HA (1993) Contribution of HER-2/neu oncogene expression to tumor grade and DNA content analysis in the prediction of prostatic carcinoma metastasis. Cancer 72: $3020-3028$

Ruiz M, Troncoso P, Bruns C, Bar-Eli M (2001) Activator protein 2alpha transcription factor expression is associated with luminal differentiation and is lost in prostate cancer. Clin Cancer Res 7: 4086-4095

Schreiber E, Matthias P, Muller MM, Schaffner W (1989) Rapid detection of octamer binding proteins with 'mini-extracts', prepared from a small number of cells. Nucleic Acids Res 17: 6419

Scott GK, Chang CH, Erny KM, Xu F, Fredericks WJ, Rauscher III FJ, Thor AD, Benz CC (2000) Ets regulation of the erbB2 promoter. Oncogene 19: $6490-6502$

Scott GK, Robles R, Park JW, Montgomery PA, Daniel J, Holmes WE, Lee J, Keller GA, Li WL, Fendly BM et al. (1993) A truncated intracellular HER2/neu receptor produced by alternative RNA processing affects growth of human carcinoma cells. Mol Cell Biol 13: $2247-2257$

Siegel PM, Ryan ED, Cardiff RD, Muller WJ (1999) Elevated expression of activated forms of Neu/ErbB-2 and ErbB-3 are involved in the induction of mammary tumors in transgenic mice: implications for human breast cancer. $E M B O J$ 18: 2149-2164

Signoretti S, Montironi R, Manola J, Altimari A, Tam C, Bubley G, Balk S, Thomas G, Kaplan I, Hlatky L, Hahnfeldt P, Kantoff P, Loda M (2000) Her-2-neu expression and progression toward androgen independence in human prostate cancer. J Natl Cancer Inst 92: $1918-1925$

Vernimmen D, Begon D, Salvador C, Gofflot S, Grooteclaes M, Winkler R (2003) Identification of HTF (HER2 transcription factor) as an AP-2 (activator protein-2) transcription factor and contribution 
of the HTF binding site to ERBB2 gene overexpression. Biochem J 370: $323-329$

Yamanaka Y, Friess H, Kobrin MS, Buchler M, Kunz J, Beger HG, Korc M (1993) Overexpression of HER2/neu oncogene in human pancreatic carcinoma. Hum Pathol 24: 1127-1134
Yarden Y, Sliwkowski MX (2001) Untangling the ErbB signalling network. Nat Rev Mol Cell Biol 2: 127-137

Zabrecky JR, Lam T, McKenzie SJ, Carney W (1991) The extracellular domain of p185/neu is released from the surface of human breast carcinoma cells, SK-BR-3. J Biol Chem 266: 1716-1720 